\title{
What Should China Learn From European Sovereign Debt Crisis
}

\author{
Sun Yifan \\ College of Management \\ Hebei University \\ Baoding, R.R.China \\ E-mail: yfsun510@gmail.com
}

\author{
Chen Lisha \\ Faculty of Management \\ Universiti Teknologi Malaysia \\ Skudai, Malaysia \\ E-mail: lschen510@163.com
}

\begin{abstract}
For China, the lesson of European countries is an important warning for China's national debt management. High levels of economic growth and fiscal revenue of cannot continue for a long time, while there is a pressure to the growth of financial expenditure, and the increase of budget deficit and national debt from the national public economic management system, the urgent demand of social transformation and supply responsibilities of public goods are not clearly defined. To understand the potential risks of the debt crisis and adopt a rational response strategy has been a practical requirement.
\end{abstract}

\section{Keywords-debt crisis; fiscal risk; government debt.}

\section{THE ORIGIN OF EUROPEAN DEBT CRISIS}

There is no doubt that the international financial crisis and debt crisis in Europe, they are not finished. This paper attempts to present the author's view on the European sovereign debt crisis' causes and its inspiration for China to prevent the risk of debt.

An important reason why the debt crisis in Europe has drown such a strong attention is that EU is one of the world's major developed economies and the operational mechanism of its market economy system should have been perfect, but why have Greece, Spain, Ireland, Portugal, Italy and many other countries been dragged into the quagmire of the debt crisis?

Firstly, management system in euro zone is unique. Still take Greece as an example, as a relatively weaker economy in the euro zone; the Greek government has a motivation to loose fiscal policy to stimulate economic growth. Before joining the euro, Greek government needs to consider many conditions and problems when takes stimulus, such as inflation, the influence of exchange rate rising on exports, and the poor economic situation would severely undermine the country's credit as well as its financing capability. However, there constraints have been greatly weakened after Greece joined the euro, because in the Greek view that the pressure of inflation can be diluted by other EU countries and the use of the same currency Euro will decrease the risk on exchange rate and secure export to some extent. Therefore, in the first few years with a relatively good economic situation, the Greek government did not fully comply with the Stability and Growth Pact and optimize its financial condition, but kept a continual loosen fiscal policy to further stimulate economic growth, that is a "negative externality" in economics.
Secondly, the inadequate control of financial risk factors. To prevent debt crisis, controllable management of debt scale is the key issue. As an important source of fiscal revenue, debt financing needs an appropriate control line in the debt management mechanism. In this regard, as early as in 1991, EU has clearly defined in The Treaty on European Union that the deficit of member country must not exceed $3 \%$, and the debt rate cannot exceed $60 \%$. However, from joining the euro in 2001 to the eve of the 2008 crisis, the average annual debt deficit reached $5 \%$, while it was only $2 \%$ of the euro-zone in the same period; Greece's current account deficit is $9 \%$ on average, on the contrary it was $1 \%$ of the euro-zone. In 2010, the deficit of Greece was $12 \%$, the debt rate was over $110 \%$, it has already far beyond the standard of EU. Although there were some differences in the deficit rate and debt rate among Spain, Ireland, Portugal, Italy and some other countries, they all exceeded the limits set by EU. These relatively small and weak economies have no strong actions to deal with high debt and low revenue, they are seem to be powerless to resist a serious impact on some unexpected factors, and finally the potential debt risk turned into a debt crisis.

Thirdly, consequences of the unsuccessful pursuit of high social welfare and economic growth. Over high deficit rate and debt rate, the lost of solvency and the broke of fiscal balance are the direct causes of the debt crisis. View from a deep level, the real culprit for the debt crisis is what resulted in the over high deficit rate and debt rate. The social welfare, we are talking about here, refers to the social welfare which is social security system centered, uses public finance as the ultimate security means, and directly increases the spending capability of social members. The national fiscal policy dominated by high welfare has exposed kinds of drawbacks in the 1970s, so that the Thatcher government had to make a significant adjustment in UK. However, due to the power of labor unions, the promotion of electoral politics and welfare concept, many European industrialized countries still maintained a high level of social security. What is particularly important is that the high level of social security accompanied by the aging population structure and the downturn of economic growth. According to a report of Statistical Office of the European Communities (Eurostat) of 2008, since the 21st century, the real growth rate of the European population is close to Zero, and there is a substantial increase in the proportion of aging people. Some experts have pointed that the recession of European economic growth is impossible to be reversed in a short time. 
The industrial hollowing of these countries is generally very severe, and made the economic competitiveness of these European countries have generally declined and restrict the creation of real wealth. While the conservative market mechanisms and human capital market of the European countries restricted the abilities of the scientific and technological personnel, which resulted in the decrease of new scientific and technological achievements' driving force on industrial development.

\section{THE WARNINGS OF EUROPEAN DEBT CRISIS’S FOR CHINA}

European debt crisis has had an enormous impact on contemporary society and economy, it has given all the other countries a profound lesson, and China is no exception. As mentioned above, fiscal deficit and government debt is an objective phenomenon, in the market economy; any country will have deficit and debt, long or short, high or low. Since the implementation of Reform and Open policy, China has gradually transferred into socialist market economy, and deficit and debt began to emerged in the operation of government finance and gradually got well known. In 1980, both of national budget deficit and government debt were 12.75 billion CNY; in 1990, these two figures were 15.043 billion CNY and 19.587 billion CNY respectively. Because of the first round of proactive fiscal policy, deficit reached 259.687 billion CNY, accounted for $2.9 \%$ of GDP, and the balance of government bonds sharply rose to 1.3011 trillion CNY, and the debt burden was $14.6 \%$ in 2000 . While in 2010, the total deficit of central government reached 1 trillion CNY, accounted for 2.2\% GDP, and financial debt of central government was 675.2 billion CNY, which is $17 \%$ of GDP.

Contrast to the deficit and debt figures of European countries, China is apparently in a low level. Therefore, some academics and politicians in China believe that debt crisis is impossible to occur in China, because there is plenty of space for the operation of financial deficit and debt. But every country should accumulate the ability to deal with the risk of debt crisis, so in my opinion, learning from European countries' experience and preventing the happen of debt risk is very important to China financial department. At present and for a long time in the future, the Chinese government will expand its responsibility on public product providing, and it will give a significant pressure on debt growth.

The public economic management system of China is not conducive to avoid the risk of government debt. In China, socialist market economic system decided that public economy is supported by public financial support of Highways and transport infrastructures have become private money-making tools. In 2011, the average profit margin of 19 highway enterprises which went public in Shanghai Stock Exchange reached 35.5\%, and the employees of highway toll station have enviable wages and welfares. I am not only want to give a simple example of how highway construction damaged the function of public products, but wish to point out that the behaviors of abusing the criteria of public product will lead to more complex and severer trouble sooner or later. Because on one hand, the behavior of abusing the criteria of public goods will inevitably depends on debt financing, and it will inevitably turn into government's finance pressure. In Beijing Jiaotong University's research report (authorized by Development and Reform Commission) on the debt problems of transportation system in China in 2011, the asset liability ratio of China's expressway construction was over $70 \%$. On the other hand, the huge projects of public products, a considerable part of which are running as public enterprises and public service. However, with the deepening of economic reform, once these operators of public products lose the protection of government, they will lose their business advantages as well and generate lots of financial debt and debt of employees' wage, welfare and employment.

\section{REFERENCES}

[1] D. McElroy, and P. Anast, . "Greece Crisis: Three Bank Workers Killed in Street Protests”. http://www.telegraph.co.uk/travel/desti nations/europe/greece.

[2] C. Geng,. “Spain Held National Wide Strikes”. http://world.people. com.cn/ GB/17536258.html

[3] X. X. Liu,. "Break the Ceiling of High Welfare, Rescue European and American Debt Crisis”. Securities Times. 2011-9-20 